\title{
THE COMBINED METAL STRUCTURES WITH THE CALCULATING REGULATION EFFORTS
}

\begin{abstract}
The results of analytical studies of the stress deformation state (SDS) regulation in combined structures are presented. A unified design model of combined systems was proposed (based on the decomposition of the system) as a beam on elastic supports, which simulates the beam stiffness and elastic support system. The essence of the calculation: first, based on decomposition of the system, the system is divided into two subsystems - major and supporting. Furthermore, using synthesis system calculated its SDS. The rationality criterions of energy efficient design are: stress equality, bending moment equality, maximal inflexibility or minimum structure mass. The mathematical model of iterative design process of rational combined structure was shown. It is shown that the main advantage of the developed calculation method for combined structures SDS regulation is calculated stress equality section of the beam stiffness, which gives them a decisive advantage in comparison with similar structures without the SDS regulation. Based on the results of the research, there were proposed new structural forms of combined systems that are protected by patents of Ukraine for inventions. The result is a decrease in the mass of metal structures up to $30 \%$. Simplified topology decreases the cost of structure manufacturing.
\end{abstract}

Keywords: model, stress deformation state (SDS), energy criterion, stress equality, mathematical model, iterative design process, combined metal structures

\section{Introduction}

Combined metal structures have a number of advantages over the others. This allows to use them for overlapping of large and medium spans. Currently, however, the use of such composite structures is limited due to insufficient knowledge of new materials, components and design approach for such structures. One of the ways to improve the combined metal structures is to create design method that allows to control

\footnotetext{
Miron Gogol, prof. PhD. Eng. National university «Lviv politekhnika», St. S. Bandery 12, Lviv, Ukraine, tel. +38 032 2582361, gogolmyron@i.ua
} 
the stress deformation state (SDS) in the design process, that does not require any additional cost [2-4]. This, in it's turn, requires the development of new methods of calculation and design forms, special studies on the regulation of structures SDS. The significance of the considered problem confirms the establishment in August 1994 in Pasadena (California, USA) of international association for the structures control (IASC - International Association for Structural Control), the first president who was a professor at George W. Housner. IASC covers a wide range of issues concerning construction and engineering structures. In Europe, an association for the structure control with a center in Italy (President Professor F. Casciati) is created and publishes journal named Journal of Structural Control [13].

There are no substantial technological limitations of combined metal structures SDS regulation. Special importance is the problem of optimal and rational analysis and design. The problem of optimal design of composite metal structures in its full extent is extremely difficult and in some cases has not completed mathematical solution. In addition, existing solution methods don't guarantee the achievement of global extremum for target functional, and so, obtained solution can be considered only relatively optimal $[1,19,22]$.

An alternative for optimal design is rational design, which, unlike optimal, does not imply the existence of a functional target, but includes additional heuristic design requirements for SDS (stress equality, bending moment equality, maximal inflexibility or minimum structure mass). That ensures structure improvement by strength criterion. This design uses structure bearing capacity most fully. Therefore, the development of theory and calculation methods of equally intense rational combined metal structures is actual, taking into account actual features of their work.

The problem mostly concerns to combined (trussing, guy rope, hanging) structures, where the main bearing element is the stiffness beam, which metal consumption largely determines technical and economic efficiency of the entire system. The rational design of stiffness beam enables efforts adjustment throughout the all system $[2,5,11,12,14,15,20]$. A typical example of such structures is trussing beam-farm with low quantity of elements $[4,5]$, in which are effectively implemented the principles of functions combining and material concentration. The proposed combined structures [8-10] are characterized by full use of the material strength due to providing stress equality in structure cross sections. Therefore, they provide significant savings in material compared to traditional designs.

The aim of the work is a improving the combined metal structures with the regulation of stress - deformation state in the design, implementation and operation. 


\section{The main material}

The proposed design method and calculation of rational combined metal structures is reduced to accounting for the influence of deformability intermediate supports of stiffness beam on correlation of supporting and span bending moments. The rationality of combined structure as a whole depends on as the intermediate supports stiffness of trussing systems so on the topology.

For example, if a single-span beam has mono extreme diagram of moment $\mathrm{M}_{\mathrm{x}}$ with the value of the extremum $\mathrm{M}_{\mathrm{c}}=\mathrm{ql}^{2} / 8$, then placing in the middle span rigid support, we get three extremes in $\mathrm{M}_{\mathrm{x}}$ diagrams with different values $\mathrm{q1}^{2} / 32$ on the supports, $\mathrm{ql}^{2} / 64$ in each span. In this case there will be a reaction of medium support $\mathrm{Rc}=5 / 8 \mathrm{ql}$, but support sagging will be $\Delta \mathrm{c}=0$. If insert not rigid but elastic support such, that $M c=0$, then the other two extremes in $M x$ diagram shall have the value $\mathrm{ql}^{2} / 32$, and elastic support settles on the value $\Delta_{\mathrm{c}}=1,25 \mathrm{ql}^{4} / 480 \mathrm{EI}$, it's reaction will be $\mathrm{R}_{\mathrm{c}}=\mathrm{q} 1 / 2$, with total decrease of $12.5 \%$ compared to reactions in a rigid support. In odder to receive equal extreme of $M_{x}$ diagram (fig. 1), it as necessary to change $R_{c}=k \Delta_{c}=f(q, I, E, I, A)$ (stiffness of elastic support), in such a way that to get all extremes values $\mathrm{ql}^{2} / 48$.

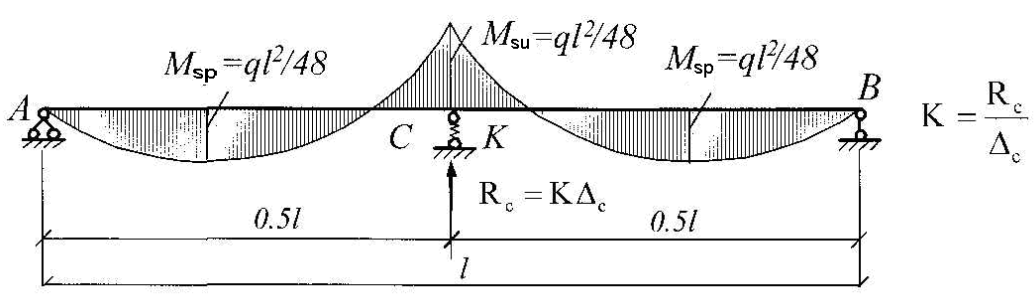

Fig.1. Equal extreme diagram of bending moments in the beam, with SDS regulation

Rys. 1. Wykres ekstremalnych, wyrównanych momentów zginających belki z regulacją SDS

Consequently, the beam efforts regulation require to change reactions values and elastic support sagging simultaneously, which characterizes the change of the system stiffness - because the elastic support sagging depends not only on truss stiffness, but also on stiffness of the beam. An elastic support stiffness is provided by truss system.

Thus the essence of the regulation of the system SDS is that we select proper stiffness of system elements, which will in its deformed state to obtain the desired distribution of forces and deformations.

So the maximum savings that can be achieved with the current regulation efforts in a continuous beam, of force to get it, shown in fig. 1, where $\mathrm{M}_{\max }=\mathrm{ql}^{2} / 48,34 \%$ less compared to a beam with a rigid support (without SDS regulation). 
Here follows the basic principle of the estimated SDS regulation of combined structures. That is a design scheme, where the beam is supported by elastic intermediate supports and rigid extreme supports [5].

This paper develops a method [18,21], which allows simultaneous solution of inverse problem - rational design, obtain and solving the direct problem of calculating the stress- deformation state design. The essence of the calculation: [7-9] initially based on decomposition of the system, the system is divided into two subsystems - the main and supporting. Furthermore, using synthesis system, its stress-deformation state is calculated. Fig. 2 shows a scheme of a mathematical model of iterative design process of rational combined metal structures.

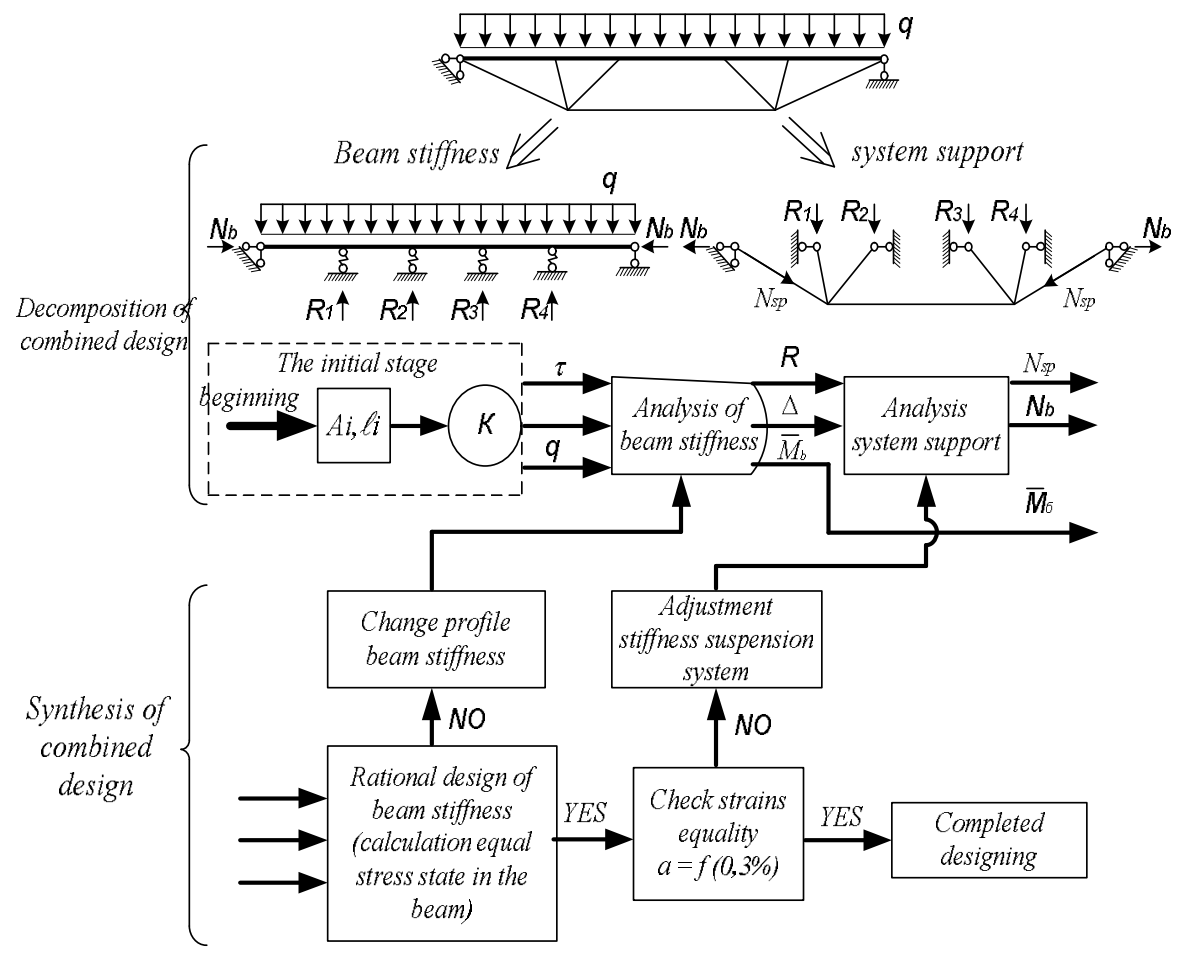

Fig. 2. Scheme of the mathematical model of iterative design process of rational combination of metal structures

Rys. 2. Schemat matematycznego modelu iteracyjnej metody projektowania racjonalnego łączenia konstrukcji stalowych

As the criterion of rationality serves energy efficient design criteria [10] as well as the requirements for stress-deformation state: stress equality, bending moment equality, maximal inflexibility, or minimum mass of structures. 
For example, lets consider SDS regulation in little element farm with span $12 \mathrm{~m}$, under loading equal to $31,2 \mathrm{KH} / \mathrm{m}$ (fig. 3a). Here design scheme of farm stiffness beam adopted as beam on elastic supports (fig.3g) [8]. For comparison, adopted design sheme for the same beam on rigid supports (fig. $3 \mathrm{~b}$ ). The values of total stress in areas near rigid supports of beam (fig.3e) exceeds the elastic limit of the metal strenth, which requires an increase cross-section of double-T profile up to № 30, but taking into deformation state (fig.3j) cross-section of double-T profile is № 27 , which saves up to $14 \%$ metal.

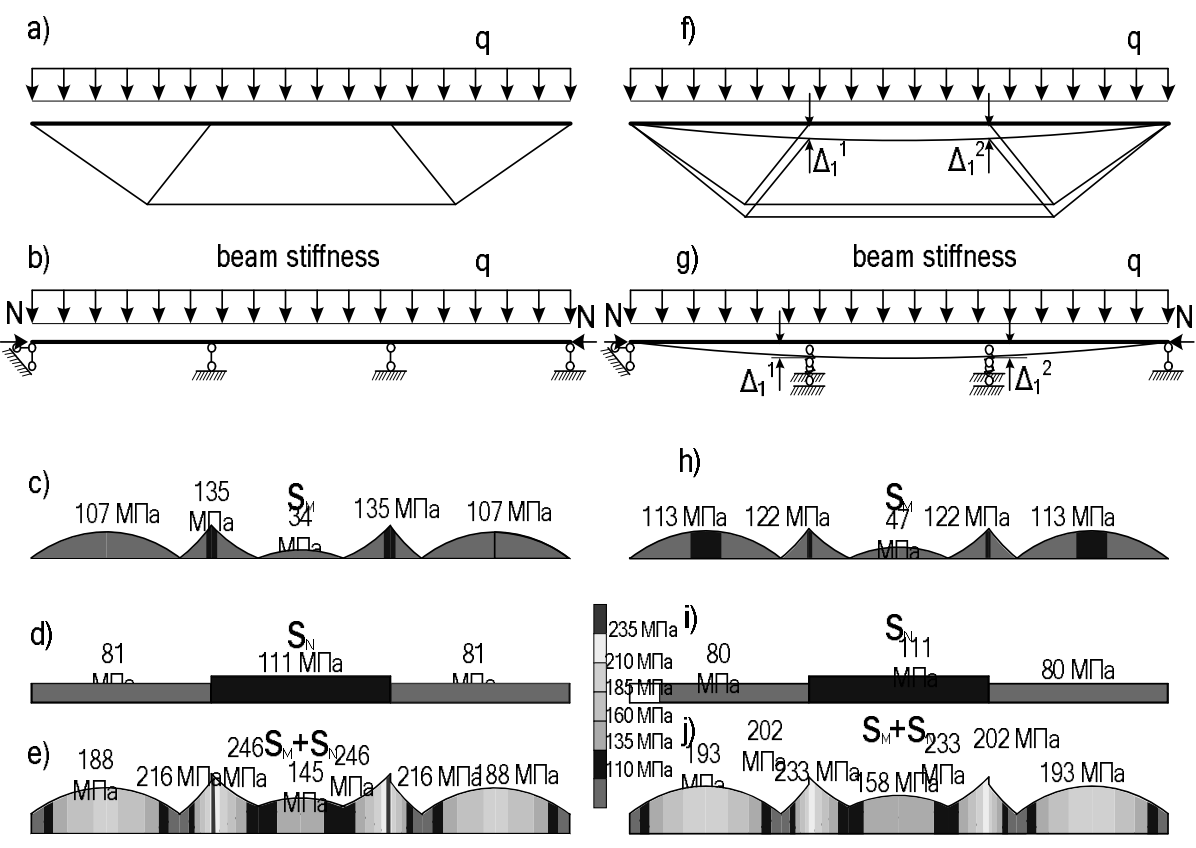

Fig. 3. Effect of support stiffness on the stress distribution: a) - scheme of frame; b) - design scheme of stiffness beam on rigid supports; f) -scheme of frame deformation; g) - design scheme of stiffness beam on elastic supports; c) - stress diagram from the moments of the beam on rigid supports; d) - stress diagrams of normal forces in beam on rigid supports; e) - the diagram of summary stress in the beam on rigid supports; h) - stress diagram from the moment in the beam on elastic supports; i) - stress diagram from the action of normal forces in beam on elastic supports; $\mathrm{j}$ ) - the diagram of summary stress in beam on elastic supports

Rys. 3. Wpływ sztywności podparcia na rozkład naprężeń: a) - schemat ramy; b) - schemat obliczeniowy sztywnej belki na sztywnych podporach; f) - schemat odkształceń ramy; g) - schemat obliczeniowy sztywnej belki na sprężystych podporach; c) - wykres naprężeń od momentu zginającego w belce na sztywnych podporach; d) - wykres naprężeń od siły osiowej w belce ze sztywnymi podporami; e) - wykres naprężeń całkowitych w belce ze sztywnymi podporami; $h$ ) - wykres naprężeń od momentu zginającego w belce na podporach sprężystych; i) - wykres naprężeń od siły osiowej w belce na podporach sprężystych; j) - wykres naprężeń całkowitych w belce na podporach sprężystych 
According to the results of our numerical studies, for projected rational farms with few elements and with equally tensed cross sections in stiffness beam (due to elastic supports stiffness increasing in truss system), their actual deflections are only about $50 \%$ of the allowable deflections according to state building codes (SBC), at less than fully loaded truss system [6] (fig. 4).

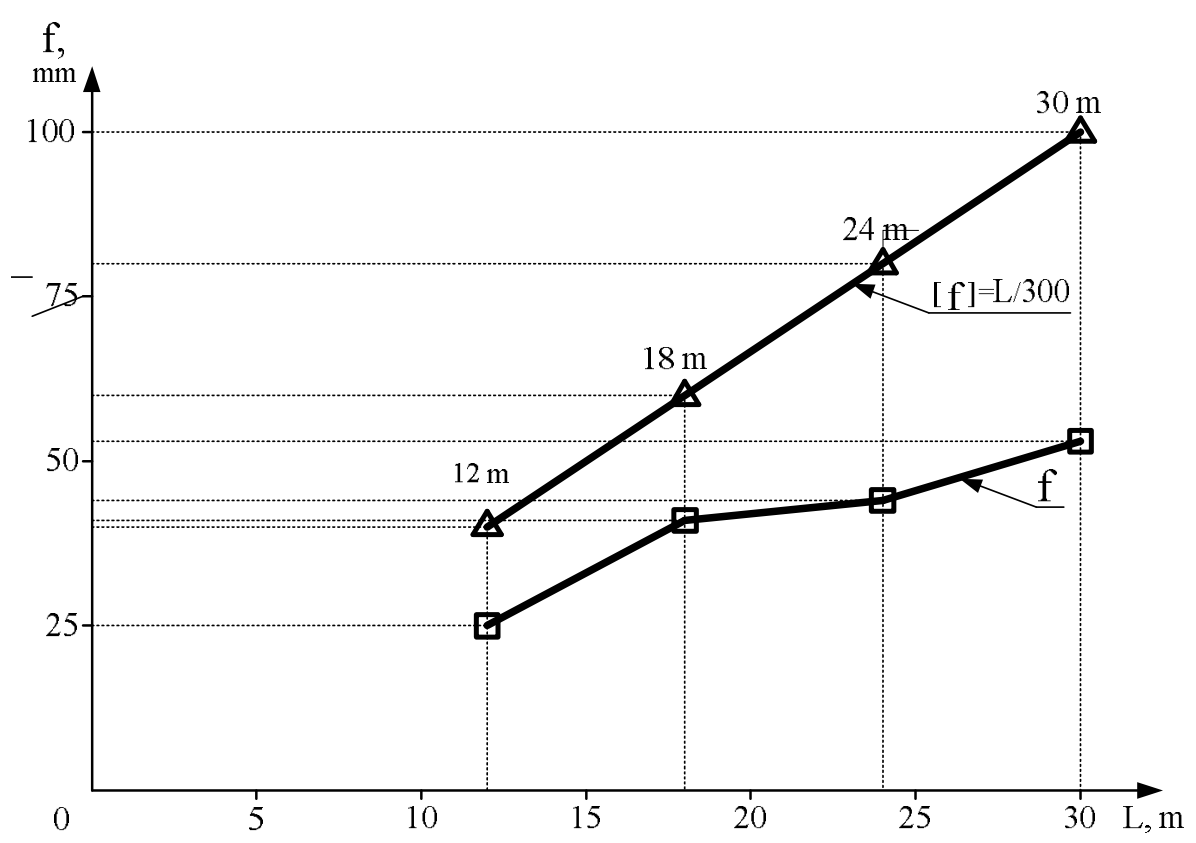

Fig. 4. Valid deflections little element trussing farms and permitted deflections on SBC: $\mathrm{f}$ - size of deflection, mm; L - span, $\mathrm{m} ; \Delta$ - permitted deflections on SBC; $\square$ - actual deflections

Rys. 4. Rzeczywiste ugięcia małych elemetów ramy kratowej i dopuszczalne ugięcia konstrukcji według norm krajowych: f - wartość ugięcia, mm; L - rozpiętość, m; $\Delta$-normowo dopuszczalne ugięcia; $\square$-ugięcia rzeczywiste

This creates a certain margin of stiffness and strength and provides an opportunity to increase the external loading. But at the same time, the calculated stresses in cross sections of stiffness beam are larger than the proportionality limit for a given grade of steel.

In order to increase efficiency (carrying capacity) combined metal structures, there was developed engineering method of calculation of rolled continuous stiffness beam of truss farm with few elements during working in the range of limited plastic deformation, which can be extrapolated to all the combined system.

For the purpose of regulatory efforts at the design stage, the suspension system of beam-farm is less than fully loaded approximately up to $20-30 \%$ of the normative value, the deflection of system is up to $50 \%$ of the allowable deflection $[\mathrm{f}]$, and in the rolling stiffness beam tensions in calculation sections 
are equal and practically do not exceed the elastic limit of steel. Thus, it is possible to increase the load on all elements of beam-farm (providing system deflection to the required [f], and accordingly stresses in stiffness beam increase to elastic-plastic level and truss system of beam-farm becomes fully loaded).

It is determined a wide range of metal combined structures for mass application in which it is advisable to regulate the SDS by means of calculation method and for which the design scheme can be taken in the form of beams on elastic intermediate supports: a large-span truss composite systems, light-metal trees, wooden structures, cable-stayed, suspension and arch-cables systems, steel concrete structures, bridge systems, structures for reinforcement and reconstruction.

Developed and published typical album and practical advice on methods of calculation and regulation SDS of combined structures used in design practice. To use these results to design practice developed program and algorithm of effort calculation method of computer language (FORTRAN-IV) [16]. The numerical comparison of the results of the calculation method proposed combined systems and software methods "Mirage" and «Scad», which once again confirmed the reliability and effectiveness of the method.

Based on the results of the research developed proposed new structural forms of combined systems with weight of less than $30 \%$ (tab.), which are protected by patents of Ukraine for inventions (patents Ukraine: № 50014, № 46383, № 48841) $[4,10]$.

Using generalized rational design methods for combined metal structures, SDS regulation method, taking into account the elastic intermediate supports of stiffness beam and improving topology, which was based on the criteria of rationality and the basic principles of formation of rational combined structures made it possible to offer new forms of rationally designed combined metal structures - combined trussing system (tab.) and to determine their rational use area.

The shape of rational combined systems based on the following basic principles: minimization of material costs and the cost of their production while ensuring rational geometrical parameters.

A significant advantage of such systems is reduced material consumption to $22-27 \%$. The concentration of the material in the main element - stiffness beam is an average of $65-70 \%$, and the number of nodes and elements compared with the typical structures is reduced at times. As can be seen from the table, these trussing system with few elements proposed with the number of elastic supports from 2 to 7 for spans 9 to $40 \mathrm{~m}$.

The most efficient use of such systems is for three elastic supports, which corresponds to an average span of 12-24 m. For large spans, in odder to provide the equal stress state in the stiffness beam it is needed more elastic supports, causing a decrease in performance. So, for spans from 12 to 40 meters it is effectively to use light truss combined farm with few elements, rationally designed on the calculation method of SDS regulation (tab.). Stiffness beam in these systems the most efficient 
design of effective rolling profiles, primarily rolling beams shelf with parallel edges and curved profiles.

Based on the proposed criteria of rationality of combined metal structures it is proved, that the mass of a continuous stiffness beam that is supported by intermediate elastic supports, compared to a beam on two supports at spans 45$60 \mathrm{~m}$, decreases rapidly in the presence of not more than three intermediate elastic supports. Rational angles braces, bands and cables combined structures relative to their weight are in the range of $30-60^{\circ}$ [8].

All above mentioned will provide high manufacturability of structures, and the above mentioned criteria generally increase rationality and efficiency of combined farm structures. Rationality each listed in rab. constructive schemes determined by the specific terms of design.

For example, scheme 1-5, 13-17 rational for large loads and schemes 6-12, 18-24 - for small loads (тab.). It extends the range of applicability of lightweight combined structures, including the most popular truss and panel - truss system, farms, cross, cable-stayed and suspension systems and steel concrete bridge structures, combined systems using rigid threads, the system of lightweight structures agricultural buildings.

These results were used in the design of such objects and structures: the plant "Carpathian Ceramics" m. Kalush, Ivano-Frankivsk oblast., in 2011 (Fig. 5); sport complex, Lviv, st. Zubrivs'ka, 2012 (Fig. 6) and pilot plant testing of mechanical, m. Lviv, 2004; Sanatorium "Geneva" m. Truskavets, 2004; business center "Pidzamche", Lviv, 2007; cement plant m. Mykolaiv, 2007; company "Alba" settlement Schirets, 2006; Company "VEEM", m. Lviv. 2007 [8,10,17].

The use of the proposed structures at construction sites during construction new and reconstruction of existing, as well as strengthening the case of builders showed their high manufacturability during manufacturing and installation.

The economic effect of the introduction of rational combined trusses with SDS regulation compared with typical designs ranging from $\$ 273$ to 484 per ton of metal structures.

\section{Conclusions}

1. It is shown that the main advantages of the developed calculation method of SDS regulating in combined structures is the possibility to reach equal tensions in calculated cross sections of the stiffness beam, which gives them a decisive advantage in comparison with similar structures without SDS regulation.

2. The given method of calculation allows to carry out necessary efforts regulation in stiffness beam without its prestressing.

3. Such regulation reduces metal consumption of combined structures up to $30 \%$, and their simplified topology reduces work the manufacture cost.

4. This method makes it possible to establish the deformation state of stiffness beam that provides equal strength of all structure elements 
5. Developed the method of rational design of combined metal structures.

6. Using the criterion of small plastic deformation (smaller or equal to 0.002) in statically indeterminate structure - beam-farm in odder to calculate a continuous rolled stiffness beam, provides equal strength of all structure elements and ensure maximum steel savings.

Table 1. New forms of rational design combined metal farms

Tabela 1. Nowe, racjonalne formy projektowania stalowych konstrukcji łączonych

\begin{tabular}{|c|c|c|c|c|c|}
\hline $\begin{array}{l}\text { № } \\
\mathrm{p} / \mathrm{n}\end{array}$ & $\begin{array}{l}\text { Scheme design c } \\
\text { combined }\end{array}$ & \begin{tabular}{|l} 
Span, \\
in $\mathrm{m}$
\end{tabular} & $\begin{array}{l}\text { № } \\
\mathrm{p} / \mathrm{n}\end{array}$ & $\begin{array}{l}\text { Scheme design } \\
\text { combined }\end{array}$ & $\begin{array}{l}\text { Span, } \\
\text { in } \mathrm{m}\end{array}$ \\
\hline 1 & & 9,12 & 13 & & 9,12 \\
\hline 2 & & $9,12,15$ & 14 & & $9,12,15$ \\
\hline 3 & & $9,12,15$ & 15 & & $9,12,15$ \\
\hline 4 & & 9,12 & 16 & & 9,12 \\
\hline 5 & & $\begin{array}{l}15,18 \\
24\end{array}$ & 17 & & $15,18,24$ \\
\hline 6 & & $\begin{array}{l}18,24 \\
30\end{array}$ & 18 & & $18,24,30$ \\
\hline 7 & 凤 & До 36 & 19 & & До 36 \\
\hline 8 & & До 40 & 20 & & До 40 \\
\hline 9 & $\gamma$ & До 40 & 21 & & До 40 \\
\hline 10 & 7 & До 36 & 22 & & До 36 \\
\hline 11 & & До 36 & 23 & 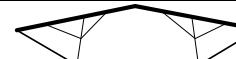 & До 36 \\
\hline 12 & $\nabla \nabla$ & До 50 & 24 & & $12,18,24$ \\
\hline
\end{tabular}




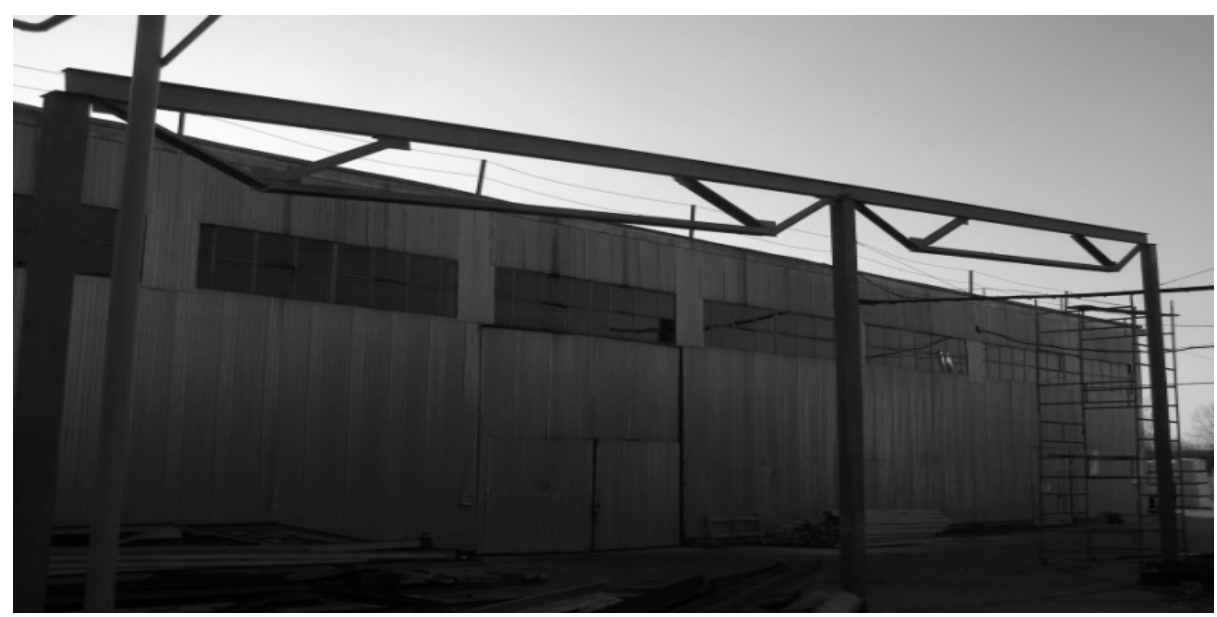

Fig. 5. Little Farm overlapping element combined with adjustment effort $\mathrm{L}=12 \mathrm{~m}$. Plant "Carpathian Ceramics" c. Kalush, Ivano-Frankivsk oblast., 2011

Rys. 5. Małe ramy wzmacniające element konstrukcji o rozpiętości L $=12 \mathrm{~m}$. Zakład „Ceramika Karpacka" m. Kałusz, obwód Iwano - Frankowski, 2011

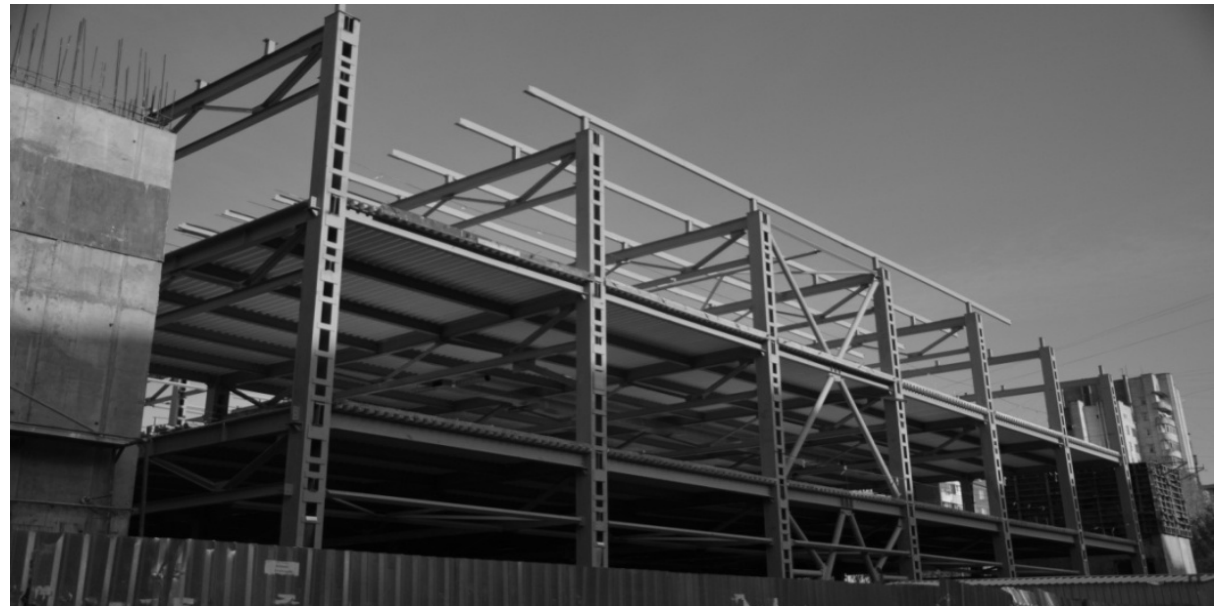

Fig. 6. . Combined farms covering, $\mathrm{L}=12$ and 18 m.Fitness centers, Lviv, st. Zubrivs'ka, 2012 Rys. 6. Wzmocnione belki stropów L $=12$ i 18 m. Centrum fitness, ul. Zubrivska, Lwów, 2012

7. The proposed new structural forms of rational combined metal structures - combined trussing systems that have reduced material consumption to $22-27 \%$.

8. Disclosure of potential regulatory for implications of such combined systems through the rational formation of stress deformation state regulation in structure cross sections at the design stage, creating a rational basis for the development of scientific bases of obtaining a new construction generation. 
9. Achievements in structural mechanics and computer engineering, research and development of new forms of design, building materials, technology, manufacturing and installation created preconditions for widespread use of modern rational combined systems.

\section{Bibliography}

[1] Advances in Steel Structures: Proceedings of the Fourth International Conference on Advances in Steel Structures 13-15 June 2005, Shanghai, China. Volume I. Edited by Z. Y. Shen, G. Q. Li, S. L. Chan. Amsterdam: Elsevier, 2005.917 p.

[2] Egorov, V. V. The development of constructive forms and methods of calculation of combined systems of strut_framed type: Authors abstract, Ph.D. thesis in Engineering science: Specielity 05.23.01 «Civil constructions, buildings and structures». St. Peterburg, 2004, 49 p. (in russian).

[3] Ferenchik, P.; Tohachek, M. Prestressed steel structures. Moscow: Strojizdat, 1979. 423 p. (in russian).

[4] Gogol, M. V. Design and calculation of rational combined metal structures. Journal of Metal Constructions. Vol. 14, No 4, pp. 253-262, 2008 (in ukrainian).

[5] Gogol, Miron. Shaping of effective steel structures. In: Civil and Environmental Engineering: scientific publications Politecniki Rzeszow. Rzeszow, No. 264, Z. 52, pp. 4356, 2009.

[6] Gogol, M. V. Calculation bulk farm when working in confined plastic deformation. Theory and practice of construction: proceedings of the National University "Lviv Polytechnic". - Lviv, No. 545. - pp. 32-35, 2005 (in Ukrainian).

[7] Gogol, M. V. Generalized method of calculation of metal structures taking into account force control. In: Mercury of National University «Lviv polytechnic» Theory and practice of civil engineering, Lviv, No 462, p. 25-34, 2002 (in ukrainian).

[8] Gogol, M. V. Method and rational design algorithm combined metal structures.. Metal structures. Vol 20, № 1. - pp. 29-43, 2014 (in ukrainian).

[9] Gogol, Myron; Peleshko, Ivan; Bilskyj, Mykhajlo. New constructive forms and their reliability. In:Quality and Reliability in Building Industry: IV. International Scientific Conference, 17-19 Oct. 2006: Conference, 17-19 Oct. 2006 : Proceedings /Technical University of Kosice. - Levoca, Slovakia : Technical University of Kosice, 2006. - S. 9.

[10] Gogol, M. V. Rational calculation and design combined metal structures. Journal of Modern industrial and civil construction. Vol 10, No. 1, - pp. 79-90, 2014 (in ukrainian).

[11] Guide to Stability Design Criteria for Metal Structures / Edited by Ronald D. Ziemian. $6^{\text {th }}$ Edition. Chichester: John Wiley \& Sons, 2010. 1120 p.

[12] Guide to Stability Design Criteria for Metal Structu_res / Edited by Theodore V. Galambos. New York: John Wiley \& Sons, 1998. 911 p.

[13] International Association for Structural Control (IASC). Vol. 3, No. 1, May, 1998. http://www.usc.edu/dept-00/dept/civil eng/structural/Newsletter_v3n1.pdf

[14] Lubinski, M.; Filipowicz, A; Zoltowski, W. Metal structures. Part 1. Warsaw: "Arcade", 2003. 646 p. (in polish).

[15] Lubinski, M.; Zoltowski, W. Metal structures. Part 2. Warsaw: "Arcade", 2004. 566 p. (in polish). 
[16] Permiakov, V. O.; Gogol, M. V. Design recommendations of well-minded metal loadcarrying structures of overhead covers and covers. Lviv: Publisher National University «Lviv Politechnique», 2006. 24 p. (in ukrainian).

[17] Permiakov, V. O.; Gogol, M. V.; Peleshko, I. D. Combined metal structures with regulation and their optimization. In: Science and innovation in current civil engineering: International research_to_practice conference, 17-19, October, 2007. St. Peterburg: SPbGASU, 2007, p. 142-145 (in russian).

[18] Permiakov, V. O.; Gogol, M. V. The problems of regulation of stress and strain state of two dimensional bar metal structures. In: Mercury National University «Lviv Politechnique»: Theory and practice of civil engineering. Lviv, No. 495, pp. 154-157, 2004 (in ukrainian).

[19] Permiakov, V. O.; Nilov, A. A.; Shymanovskyi, O. V. Edited by Permiakov, V. O.; Shymanovskyi, O. V. Metal structures. Kyiv: Publisher «Steel», 2008. 812 p. (in ukrainian).

[20] Pichugin, S. F.; Semko, A. V.; Trusov, G. N. Modern problems of bearing steel structures designing for industrial and civilian structures. In: Modern Industrial and Civil Construction, Volume 1, No 1, p. 53-66, 2005 (in ukrainian).

[21] Trofimovich, V. V.; Permiakov, V. A. Optimal design of metal structures. Kyiv: Constructor, 1981. 136 p. (in russian).

[22] Yankovskii, A. P. Equal stressed reinforcing of thinslab structure: Doctoral dissertation in Physico-Mathematical Science. 01.02.04. Novosibirsk, 2007. 48 p. (in russian).

\section{LACZONE KONSTRUKCJE METALOWE ZGODNE \\ Z REGULACJAMI OBLICZENIOWYMI}

\section{Streszczen ie}

W artykule zostały zaprezentowane wyniki badań analitycznych konstrukcji łączonych według przepisów w stanie odkształconym (SDS). Zaproponowano zunifikowany model projektowy (oparty na dekompzycji struktury), jako belkę na sprężystych podporach które imitują sztywność belki i sprężystego systemu podpierającego. Istota obliczeń polega na rozdziale konstrukcji na podkonstrukcję główną i drugorzędną. Ponadto, wykorzystując syntezę oblicza się ją w stanie SDS. Racjonalne kryteria metody energetycznej to: równowaga naprężeń, wyrównanie momentów zginających maksymalna sztywność lub minimalna masa konstrukcji. Przedstawiono również matematyczny model iteracyjnego procesu projektowania racjonalnej konstrukcji łączonej. Wskazuje on, że główną zaletą opracowanej metody obliczeniowej dla przekroju usztywnionej belki uzyskano korzyści w stosunku do podobnej konstrukcji bez wykorzystania przepisów SDS. Na podstawie wyników badań, zaproponowano nowe formy konstrukcji łącznych, które są chronione patentem Ukrainy. Uproszczona topologia zmniejsza koszty produkcji i masę konstrukcji o $30 \%$.

Słowa kluczowe: model, stan wzmocnienia (SDS), kryterium energetyczne, równowaga naprężeń, model matematyczny, iteracyjny proces projektowy, łączone konstrukcje metalowe 